\title{
POTENS PENINGKATAN PEMBERDAYAAN WAKAF DI KABUPATEN TANAH DATAR
}

\author{
Elimartati
}

\begin{abstract}
The study analyzes the potential, opportunities, human resources and challenges in improving wakaf empowerment in Tanah Datar. The method that used in this research is a field research. To collect data that needed in this study is by interviews and documentation. Data was analyzed by descriptive qualitative. Result of this study is expected to produce guidelines or rule for the conduct of wakaf and can be used as a foothold in making policies. Base on data, potential of wakaf in in Tanah Datar about 639 locations already have wakaf certificate (AIW). A religious community of Tanah Datar people could be more efective to improve wakaf empowerment by using the rule that stated by government to manage of wakaf in Tanah Datar. And this rule also To avoid any mistake or human error in mangement to empower of wakaf.
\end{abstract}

Keywords: Wakaf, Potential, Empowerment.

\section{PENDAHULUAN}

Wakaf merupakan dana sosial yang potensial bagi masyarakat Indonesia untuk meningkatkan kesejahteraan umum. Fungsi sosial wakaf merupakan aset yang amat bernilai (Efendi, 2004: 409) sebagai sumber ekonomi. Sedangkan fungsinya sebagai ibadah, merupakan amal yang pahalanya akan terus mengalir selama harta wakaf itu dimanfaatkan. Sebagaimana yang disebutkan dalam hadits: (Muhammad al-Syaukany):

$$
\begin{aligned}
& \text { عن ابي هر يرةرضي الله عنه قال ان النبي } \\
& \text { صلى الله عليه ووسلم:قال إذامات الإنسان } \\
& \text { انقطع عمله الامن ثلاثة صدقةجارية أوعلم } \\
& \text { ينتفع به اوولدصالح يدعوله }
\end{aligned}
$$

Dari Abu Hurairah ra. Sesungguhnya Nabi Muhammad SAW. Bersabda "apabila mati seorang manusia (anak Adam) maka terputuslah amalnya, kecuali tiga perkara yaitu: sedekah jariyah, ilmu yang bermanfaat, dan anak shaleh yang berdo' a untuk orang tuanya (HR Bukhary).

Wakaf sebagai pranata keagamaan yang memiliki potensi dan manfaat ekonomi perlu dikelola secara efektif dan efisien untuk kepentingan ibadah dan memajukan kesejahteraan umum. Di Indonesia wakaf merupakan perbuatan hukum yang telah lama hidup dan dilaksanakan dalam masyarakat. Pada zaman penjajahan Belanda, pemerintah Kolonial Belanda pernah mengeluarkan berbagai peraturan yang mengatur tentang persoalan wakaf, antara lain Surat Edaran Sekretaris Governemen pertama tanggal 31 Januari 1905, No. 435, tanggal 4 Juni 1931 No. 136/ A, tanggal 24 Desember 1934 No. 1361 No. 3088/A dan tanggal 27 Mei 
1935 No. 1273/A. (Depag RI, 2007: 3-4). Setelah kemerdekaan Rebuplik Indonesia, pemerintah menerbitkan Peraturan Pemerintah Nomor 28 Tahun 1977 tentang Perwakafan Tanah Milik dalam rangka penertiban dan pengamanan tanah wakaf. Untuk penyempurnaan hukum materi tentang wakaf berdasarkan Inpres Nomor 1 Tahun 1991 Presiden menetapkan Kompilasi Hukum Islam yang juga mengatur tentang wakaf dan dalam rangka penyempurnaannya disyahkan UndangUndang Nomor 41 Tahun 2004 tentang Wakaf serta Peraturan Pemerintah Nomor 42 tahun 2006 tentang Pelaksanaannya.

Salah satu dari tujuan peraturan yang dikeluarkan tentang wakaf adalah untuk mengamankan, mengatur dan mengelola harta wakaf secara baik agar lebih terjaga dan terawat serta memberi manfaat yang besar bagi masyarakat. Namun kenyataannya secara faktual banyak harta wakaf yang tidak terawat dan terkelola secara baik. Umumnya tanah-tanah wakaf pengelolaannya bersifat komsumtif dan tradisional Sempitnya pemahaman masyarakat terhadap pengertian wakaf dan bentuk-bentuk benda yang dapat diwakafkan pada umumnya berupa benda tidak bergerak dan kebanyakan untuk kepentingan peribadatan seperti masjid mushollah, madrasah. Pemakaman Dalam pelaksanaan wakaf, wakif kebanyakan menyerahkan pengelolaannya kepada orang yang dianggap panutan dalam lingkup masyarakat tertentu seperti pengurus masjid (Depag RI, 2007: 38).

Pratek wakaf yang terjadi dalam kehidupan mayarakat belum sepenuhnya berjalan tertib dan efisien, sehingga dalam berbagai kasus harta wakaf tidak terpelihara sebagaimana mestinya, terlantar atau beralih ketangan pihak ketiga dengan cara melawan hukum. Pengelolaan benda wakaf belum sesuai dengan peraturan tentang wakaf. Sehingga fungsi wakaf mewujudkan potensi dan manfaat ekonomis harta benda wakaf untuk kepentingan ibadah dan untuk memajukan kesejahteraan umum, belum tercapai. Hal ini dapat dipertanyakan apakah disebabkan karena kelalaian pelaksana dan pengelola wakaf atau ketidak tahuannya terhadap tugas dan tanggung jawabnya sebagaimana yang diatur dalam Undang-Undang dan peraturan pelaksanaannya.

Sebagai suatu ilustrasi dapat dikemukakan data lapangan di Kantor Kementrian Agama Kabupaten Tanah Datar dari laporan perkembangan kegunaan harta wakaf Kabupaten Tanah Datar tahun 2009 dengan jumlah lokasi wakaf 639 yang luasnya $760,185 \mathrm{~m}^{2}$, hanya 61 lokasai yang produktif dengan luas 
106,587 $\mathrm{m}^{2}$. Menyangkut dengan tanah wakaf yang telah disertifikasi berjumlah 251 lokasi sekitar 39,30\% dengan luas 315,285 M2 41,50\%, artinya 60,70\% belum punya sertifikat wakaf (Kemenag, 2009).

Potensi wakaf yang ada di Kabupaten Tanah Datar bila dikelola secara baik dan diproduktifkan, tentunya akan memberikan manfaat ekonomi yang besar terhadap masyarakat. Nazhir wajib mengelola dan mengembangkan harta benda wakaf sesuai dengan tujuan, fungsi, dan peruntukannya (Pasal 42 UU No 41 tahun 2004). Pengelolaan dan pengembangan harta benda wakaf oleh Nazhir dilaksanakan sesuai dengan prinsip syariah dan dilakukan secara produktif. Nazhir wakaf menurut Undangundang Nomor 41 Tahun 2004 Pasal 1 ayat (4) adalah pihak yang menerima harta benda wakaf dari Wakif untuk dikelola dan dikembangkan sesuai dengan peruntukannya. Nazhir wakaf meliput perseorangan, organisasi, atau badan hukum.

Nazhir sebagai pemegang amanat untuk memelihara dan mengurus harta benda wakaf, mempunyai beberapa kewajiban, dalam Pasal 11 Undang-undang Nomor 41 Tahun 2004, yang dipertegas dengan Pasal 13 Peraturan Pemerintah Nomor 42 Tahun 2006 disebutkan bahwa Nazhir mempunyai tugas-tugas, antara lain 1) melakukan pengadministrasian harta benda wakaf; 2) mengelola dan mengembangkan harta benda wakaf sesuai dengan tujuan, fungsi dan peruntukkannya; 3) mengawasi dan melindungi harta benda wakaf; dan 4) melaporkan pelaksanaan tugas kepada Badan Wakaf Indonesia.

Potensi wakaf yang dikelola secara baik dan profesional akan menghasilkan manfaat yang besar umpanya mesjid yang dipakai hanya untuk melaksanakan ibadah yang sifatnya konsumtif, dapat dikembangkan dengan mendampinngkan pengelolaanya yang bersifat produktif. Yaitu dengan mengembangkan bangunannya yang satu lantai menjadi lima lantai, sebahagiannya digunakan untuk tempat beribadah dan yang lainnya digunakan untuk bisnis dapat disewakan untuk perkantoran atau manfaatkan pertokoan tempat jualan.

Nazhir wakaf yang telah melaksanakan tugasnya dengan baik, dan mampu meningkatkan produktifitas benda wakaf berhak memanfaatkan hasil wakaf maksimal 10\% sebagaimana yang diatur dalam pasal 12 Undang-Undang wakaf. Namun kenyataan di lapangan Nazhir wakaf belum berjalan sebagaimana yang diamanatkan dalam undang- undang. Sebagai ilustrasi dapat dikemukakan kedaan Nazhir wakaf di Kecamatan Lima Kaum Kabupaten Tanah Datar yang 
terletak di pusat pemerintahan Tanah Datar yakni di Kota Batusangakar. Kecamatan Lima Kaum terdiri dari lima nagari dan 33 Jorong, berdasarkan data Kantor Urusan Agama ( KUA ) Kecamatan Lima Kaum pada bulan Juli tahun 2009 perkembangan data tanah wakaf berjumlah 52 dengan rincian tahun surat keputusan Nazhir wakaf tahun 1978 satu (1) wakaf, tahun 1981-1985 berjumlah 23 wakaf dan tahun 1986-1991 berjumlah 5 wakaf, yang tidak diketahui tahun surat keputusan tentang pengangkatan Nazir berjumlah 23 wakaf. Membaca data wakaf tersebut dapat dipahami bahwa Nazhir wakaf sejak dianggkat tidak pernah diganti. Sedangkan dalam Peraturan Pemerintah nomor 42 tahun 2006 pasal 14 dinyatakan bahwa 1) masa bakti Nazhir adalah 5 (lima) tahun dan dapat diangkat kembali; dan 2) pengangkatan kembali Nazhir sebagaimana dimaksud pada ayat (1) dilakukan oleh BWI, apabila yang bersangkutan telah melaksanakan tugasnya dengan baik dalam periode sebelumnya sesuai ketentuan prinsip syariah dan peraturan perundang undangan.

Data dari Kantor Kementerian Agama Kabupaten Tanah Datar dan Kecamatan Lima Kaum mengambarkan bahwa peruntukannya hanya terfokus untuk lahan bangunan tempat ibadah dan sekolah, belum banyak kelihatan wakaf yang produktif. Berdasarkan hal di atas menimbulkan pertanyaan kenapa potensi wakaf di Tanah Datar belum terberdayakan sebagaimana mestinya sehingga masih sedikit wakaf yang bersifat produktif, bagaimana peluang dan sumberdaya manusianya dalam pelaksanaan dan pengelolaan wakaf di Kabupaten Tanah Datar. Apakah pembinaan dan pengawasan terhadap pelaksanaan dan pengelola wakaf dilaksanakan sesuai dengan peraturan yang ada, dan siapa yang melakukannya serta apa program dan upaya yang dilakukan oleh para pelaku, pengelola dan pengawas benda wakaf dalam rangka peningkatan pengelolaan dan produktifitas wakaf di Kabupaten Tanah Datar? Apa hambatan atau tantangan dalam meningkatkan pemberdayanan dan pruduktifitas wakaf di Kabupaten Tanah Datar?

Kabupaten Tanah Datar dipilih sebagai lokasi penelitian adalah karena masyarakat Kabupaten Tanah Datar agamis, penduduk asli dari wialayah ini tidak ada yang menganut selain agama Islam dan masyarakatnya mempunyai falsafah adat basandi syara', syara' basandi Kitabullah (ABSSBK). Seharusnya masyaraktnya dapat mengambarkan pelaksanaan wakaf yang berpedoman kepada peraturan yang telah ditetapkan oleh pemerintah. Wakaf adalah 
salah satu ibadah yang sangat dianjurkan dan merupakan salah satu sumber dana dalam mewujudkan kemaslahatan umat.

\section{METODE PENELITIAN}

Jenis penelitian adalah penelitian lapangan dengan pendekatan kualitatif. Teknik pengumpulan data adalah wawancara dengan pegawai Kementerian Agama Kabupaten Tanah Datar dan Kepala Kantor Urusan Agama, serta studi dokumentasi. Langkah yang dilakukan dalam penelitian ini adalah mengadakan inventarisasi terhadap masalah yang berhubungan dengan masalah yang diteliti. Selanjutnya menetukan lokasi penelitian dan sumber data penelitian. Langkah berikutnya adalah membuat daftar wawancara dan melakukan wawancara untuk mengumpulkan data di lapangan serta megumpulkan dokumen yang terkait dengan masalah yang diteliti. Setelah data terkumpul dilakukan analisa data dan kemudian data yang ada diinterpretasikan, dibahas dan disimpulkan, terakhir data yang telah diolah dideskripsikan dan dilaporkan dalam bentuk hasil penelitian.

\section{HASIL PENELITIAN DAN PEMBAHASAN}

Wakaf di Indonesia telah diatur dalam beberapa peraturan. Menurut Peraturan Pemerintah Nomor 28 Tahun 1977 wakaf merupakan perbuatan hukum seseorang/ badan hukum yang memisahkan sebagian harta kekayaannya yang berupa tanah milik dan melembagakannya untuk selamalamanya untuk kepentingan peribadatan atau keperluan umum lainnya sesuai dengan ajaran agama Islam. Kompilasi Hukum Islam berdasarkan Inpres No: 1 tahun 1991 pasal 215 (1) mendefinisikan wakaf dengan perbuatan hukum seseorang atau kelompok orang atau badan hukum yang memisahkan sebagian dari benda miliknya dan melembagakannya untuk selama-lamanya guna kepentingan ibadah atau untuk keperluan umum lainnya sesuai dengan ajaran agama Islam. Sedangkan menurut Undang-Undang Nomor 41 tahun 2004 tentang wakaf pasal 1 (1) menyebutkan bahwa yang dimaksud dengan wakaf adalah perbuatan hukum Wakif untuk memisahkan dan/ atau menyerahkan sebagian harta benda miliknya untuk dimanfaatkan selamanya atau jangka waktu tertentu sesuai dengan kepentingannya guna keperluan ibadah dan/atau kesejahteraan umum menurut syariah.

Berdasarkan defenisi menurut peraturan perundang-undangan yang telah dikemukakan di atas, terdapat beberapa perbedaan maksud wakaf antara satu sama lain. Dalam Peraturan Pemerintah Nomor 
28 Tahun 1977 yang dikategorikan kepada harta benda wakaf hanyalah berupa tanah milik saja. Akan tetapi dalam Kompilasi Hukum Islam, pengertian wakaf telah mengalami perkembangan, karena yang dikategorikan sebagai harta benda wakaf adalah benda milik yang diwakafkan untuk selama-lamanya bukan hanya tanah milik saja, sedangkan dalam Undang-undang Nomor 41 Tahun 2004, yang bisa dijadikan harta benda wakaf adalah benda milik yang dalam undang-undang ini lebih dijelaskan secara spesifik dan wakaf itupun boleh untuk selama-lamanya maupun untuk sementara waktu.

Berdasarkan definisi di atas dapat dipahami bahwa wakaf adalah penyerahan atau pemberian hak milik yang bersifat kekal bendanya, dan tidak boleh dilakukan perpindahan milik, serta manfaatnya dipergunakan untuk kepentingan ibadah dan kepentingan umum yang mengharapkan keridhaan Allah SWT. Dengan demikian harta wakaf dipergunakan untuk kemaslahatan umum secara berkelanjutan tanpa menghilangkan harta asal. Dalam kondisi tertentu wakaf dapat dilakukan untuk sementara waktu.

Dari beberapa definisi wakaf yang disebutkan di atas dapat diambil suatu pemahaman bahwa 1) harta wakaf keluar atau terputus dari hak milik orang yang mewakafkan dan menjadi milik Allah atau umum. Begitulah menurut pendapat sebagian ulama. Sebagian yang lain berpendapat bahwa harta wakaf masih tetap menjadi milik orang yang mewakafkan; 2) Yang disedekahkan hanya manfaatnya saja, sedangkan bendanya (aslinya) harus tetap atau utuh;3) kegunaan wakaf adalah untuk fi sabilillah yaitu sesuatu kebutuhan yang sesuai dengan ajaran agama Islam (syari'at); 4) boleh mewakafkan manfaat suatu benda; dan 5) wakaf dilakukan untuk selama-lamanya dan dapat juga untuk sementara.

Peraturan Pemerintah Nomor 28 Tahun 1977 mengatur benda wakaf hanyalah tanah milik saja. Dan KHI disebutkan bahwa yang termasuk dalam harta wakaf adalah harta benda, benda wakaf menurut KHI Pasal 215 (4) sudah mulai bersifat umum, karena benda wakaf tidak hanya berupa tanah milik saja, akan tetapi segala benda baik bergerak atau tidak yang memiliki daya tahan dan bernilai. Sedangkan dalam Undang-undang Nomor 41 Tahun 2004 Pasal 16 lebih merinci hal yang meliputi benda tidak bergerak dan benda bergerak. Hal ini terjadi karena seiring dengan perkembangan zaman, sehingga sesuatu yang bisa bermanfaat untuk kemaslahatan umum secara berkesinambungan dengan tidak menghilangkan harta aslinya, maka 
dapat dikategorikan menjadi harta benda wakaf. Undang-Undang juga mengatur tentang wakaf untuk selama-lamanya dan sementara waktu.

Tujuan wakaf adalah memanfaatkan harta benda wakaf sesuai dengan fungsinya. Fungsi wakaf menurut Pasal 5 Undang-undang Nomor 41 Tahun 2004 adalah untuk mewujudkan potensi dan manfaat ekonomis harta benda wakaf untuk kepentingan ibadah dan untuk memajukan kesejahteraan umum. Nazhir menurut Undang-undang Nomor 41 Tahun 2004 Pasal 1 (4) adalah pihak yang menerima harta benda wakaf dari Wakif untuk dikelola dan dikembangkan sesuai dengan peruntukannya. Nazhir wakaf meliput perseorangan, organisasi, atau badan hukum.

Mengenai pengelolaan dan pengembangan harta benda wakaf diatur dalam Pasal 42-46 Undang-undang Nomor 41 Tahun 2004, yang dipertegas dengan Pasal 45-48 Peraturan Pemerintah Nomor 42 Tahun 2006. Perubahan peruntukkan harta benda wakaf diatur dalam Pasal 44 Undangundang Nomor 41 Tahun 2004 menyebutkan bahwa: Ayat (1)“Dalam mengelola dan mengembangkan harta benda wakaf, Nazhir dilarang melakukan perubahan peruntukkan harta benda wakaf kecuali atas dasar izin tertulis dari Badan Wakaf Indonesia" Ayat
(2)“Izin sebagaimana dimaksud pada ayat (1) hanya dapat diberikan apabila harta benda wakaf ternyata tidak dapat dipergunakan sesuai dengan peruntukan yang dinyatakan dalam ikrar wakaf".

Kabupaten Tanah Datar (Profil Kabupaten Tanah Datar) dikenal sebagai Luhak Nan Tuo, karena diyakini dari daerah inilah asal-usul orang Minangkabau sebelum mereka berpindah ke bagian lain Sumatera Barat seperti ke Luhak Agam, Luhak 50 Kota dan daerah lain. Luhak Nan Tuo, julukan lain dari Kabupaten Tanah Datar. Ada suatu keyakinan bagi masyarakat Minangkabau bahwa asal usul orang Minangkabau berasal dari Kabupaten Tanah Datar, tepatnya dari Dusun Tuo Pariangan Kecamatan Pariangan. Sebagai buktinya masih terdapat sawah satambang bahiah (sawah seikat benih), lurah nan indak baragin (lurah yang tidak ada angin), galundi nan baselo (galundi yang bersela), dan kuburan panjang Datuk Tantejo Gurhano yang dikenal sebagai arsitek rumah gadang (rumah adat Minangkabau).

Tatanan sosial Islam dalam masyarakat Minangkabau telah meletakakan pondasi Islam dalam masyarakat Minangkabau. Telah meletakkan pondasi adat Islamiyah dan meninggalkan adat jahiliyah. Penjelmaan Islamiyah dari adat Jahiliyah ini berwujud secara nyata dalam filsafat 
Minangkabau Adat Basandi Syara', Syara' Basandi Kitabullah, Syara' Mangato, Adat Mamakai, Alam Takambang Jadi Guru".

Adat dan syara' bersumber dari dua sumber budaya yang berbeda, tetapi keduanya secara fundamental, memiliki kesamaan dan kesejalanan dalam cara pandang. Adat disatu sisi adalah ajaran kehidupan yang bersifat filosofi kultur, yang menawarkan kearifan kearifan budaya dengan cara berguru pada alam yang bersifat kontekstual dengan konsep Alam Takambang Jadi Guru. Syara' adalah norma dan ketentuan agama yang berorientasi keimanan mengacu pada kitab suci Alguran dan Hadis Rasulullah SAW yang bersifat absolut. Falsafah adat memberikan nilai tambah terhadap psikologis bahwa adat mengacu pada ajaran budi dan kearifan budaya, sementara ajaran Islam memberi isi kepada hal-hal yang bersifat spiritual.

Falsafah adat yang berlandaskan syariat ini sekaligus membentuk warna keagamaan masyarakat Minangkabau yang Islami. Secara praktis, landasan syariat ini menunjukan bahwa tidak ada masyarakat Minangkabau yang tidak menganut agama Islam. Berdasakan hal ini dapat dipahami bahwa sulit memisahkan antara adat dan agama Islam dalam masyarakat Minangkabau. Falsafah Adat basandi syara', Syara' Basandi Kitabullah
(ABS-SBK), pada akhirnya menjadi falsafah yang mengontrol tindakan, perbuatan serta nilai dan sikap kultur Minangkabau dalam satu kesatuan yang memiliki kearifan budaya yang dilindungi oleh kekuatan internal kemasyarakatan yang akhirnya menentukan arah kehidupan peradabannya.

Sebagai daerah yang beriklim tropis, Kabupaten Tanah Datar memiliki berbagai potensi, seperti di bidang pertanian, peternakan, pariwisata dan lain-lain. Kawasan hutan yang dimilki seluas $47.440 \mathrm{~km}^{2}(35,51 \%)$ dari luas keseluruhan Kabupaten Tanah Datar. Areal persawahan seluas $28.910 \mathrm{~km}^{2}$ ujud $(21,64 \%)$, pertanian tanah kering $18.245,1 \mathrm{~km}^{2}(13,66 \%)$, perkebunan $16.833,50 \mathrm{~km}^{2}(12,60 \%)$, rawa/ danau $6.420 \mathrm{~km}^{2}(4,81 \%)$, kebun campuran $5.190 \mathrm{~km}^{2}(3,88 \%)$, tanah tandus $1.208 \mathrm{~km}^{2}$ $(0,90 \%)$ dan kolam ikan $863,50 \mathrm{~km}^{2}(0,65 \%)$.

Masyararakat Kabupaten Tanah Datar dikenal agamais, karena memegang teguh ajaran agamanya yang terlihat dalam kehidupan sehari-hari. Kondisi ini dapat terjadi karena ditunjang oleh banyaknya sarana keagamaan yang tumbuh dan berkembang di tengah-tengah masyarakat. Di kabupaten Tanah Datar 290 buah masjid, 251 buah mushalah, 1093 buah TPA, 239 majlis taklim, 103 organisasi remaja masjid dan 54 grup kesenian bernafaskan Islam. 
Tanah yang telah diwaqafkan oleh masyarakat untuk kegiatan keagamaan mencapai 639 tanah wakaf, dengan luas lebih kurang 760,185 $\mathrm{m}^{2}$ yang terdiri dari tanah rumah ibadah, madrasah/sekolah, telah disertifikatkan berjumlah 251 lokasi sekitar 39,30\% dengan luas 315,285 $\mathrm{M}^{2}$ $(41,50 \%$, artinya $60,70 \%$ belum punya sertifikat wakaf.(Kemenag.,2009)

Pengelolaan wakaf secara profesional ditandai dengan pemberdayaan potensi masyarakat secara produktif. Keprofesionalan yang dilakukan meliputi manajemen, sumber daya manusia (SDM), kenaziran, pola kemitraan usaha, bentuk benda wakaf, peruntukan wakaf dan dukungan political will pemerintah secara penuh.

Semangat pemberdayaan potensi wakaf secara profesional produktif tujuannya adalah semata-mata untuk kepentingan kesejahteraan masyarakat, agar dapat memperbaiki keterpurukan ekonomi yang saat ini sangat menyedihkan, baik di bidang pendidikan, kesehatan, tehnologi maupun bidang sosial lainnya. Pemberdayaan wakaf secara produktif melibatkan seluruh potensi keumatan dengan dukungan penuh dari pihak-pihak terkait, dan mempedomani UU No. 41 tentang wakaf dan peraturan pelaksanaannya serta dukungan dari UU Otonomi Daerah, peran
Perda dan kebijakan nasional dan lain-lain.

Melihat potensi pemberdayaan wakaf di Kabupaten Tanah Datar, berikut ini penulis gambarkan hasil penelitian yang datanya dikumpulkan dari lokasi peneltian yang difokuskan kepada batasan masalah yang telah ditetapkan sebagai mana yang akan dipaparkan berikut ini.

Potensi wakaf di Kabupaten Tanah Datar 1) banyaknya jumlah tanah wakaf yang ada Data yang diperoleh dari Kementrian Agama Kabupaten Tanah Datar bersumber dari laporan Direktori Tanah Wakaf tahun 2009 berjumlah 639 lokasi dengan luas $760,185 \mathrm{Km}^{2}$ ( \%)dari luas wilayah Kabupaten Tanah Datar 133.600 Ha $\left(1.336 \mathrm{Km}^{2}\right)(100 \%)$ yang tersebar dalam 14 kecamatan; 2) kebanyakan dari tanah wakaf sudah punya AIW. Tanah wakaf di Kabupaten Tanah Datar yang telah terdata berjumlah 639 lokasi, semuanya sudah punya Akta Ikrar Wakaf (AIW). Berdasarkan informasi dari Kepala KUA Kecamatan yang diwawancarai mengatakan masih banyak tanah wakaf yang belum terdata dan belum punya AIW atau APAIW. Jumlah tanah wakaf yang sudah punya AIW ini merupakan potensi wakaf yang dapat diberdayakan dan dikembangkan menjadi wakaf produktif; 3) sudah banyak tanah wakaf yang disertifikatkan. Tanah Wakaf agar mempunyai kekuatan 
hukum yang dapat dibuktikan harus disertifikatkan. Di Kabupaten Tanah Datar berdasarkan hasil Laporan Kementerian Agama Kabupaten Tanah Datar bahwa tanah wakaf yang telah punya sertifikat berjumlah 251 Lokasi (39,30\%) dengan luas $315,285 \mathrm{~m}^{2}$ ( 41,50 \%), dan 388 lokasi (60.70 $\%)$ dengan luas $444,900 \mathrm{~m}^{2}(58,50 \%)$ dalam proses sertifikat, masing-masing KUA Kecamatan memprogramkan 2 sampai 3 lokasi untuk disertifikatkan tiap tahunnya. Tanah wakaf sudah disertifikatkan ada juga peruntukanya yang produktif lebih kurang 61 lokasi; 4) adanya nazhir wakaf. Hasil wawancara dengan dengan bapak Arif Zunzul Maizal penyelenggara zakat dan wakaf di Kemetrian agama Kabupaten Tanah Datar mengatakan 75\% tanah wakaf yang ada telah mempunyai Nazhir wakaf. Data diperoleh dari KUA kecamatan mengatakan Nazhir wakaf itu ada hanya untuk melengkapi persyaratan wakif mewakafkan tanahnya, setelah wakaf terlaksana nazhir tidak berfungsi lagi. Tanah wakaf itu kebanyakan diurus oleh pengurus dari peruntukan wakaf seperti pengurus masjid, mushalla atau surau dan pengurus suatu perguruan bila tanah wakaf untuk sekolah dan tanah wakaf yang berbentuk sawah, lahan perkebunan dan kolam ikan juga pengurus yang mengurusnya. Artiya setelah tanah menjadi tanah wakaf, maka Nazhir seolah-olah tidak ada fungsi lagi.

Peruntukan tanah wakaf di Kabupaten Tanah Datar pada umumnya adalah untuk sarana dan kegiatan ibadah, dan sedikit sekali diperuntukan untuk kegiatan sosial. Dari 639 jumlah lokasi tanah wakaf dengan luas $760,185 \mathrm{~m}^{2}$, diperuntukan untuk masjid berjumlah 270 lokasi dengan luas $353,967 \mathrm{~m}^{2}$, langgar/mushallah 177 lokasi dengan luas $74,202 \mathrm{~m}^{2}$, madrasah 95 lokasi dengan luas 186,423 $\mathrm{m}^{2}$, kuburan 1 lokasi dengan luas $1,346 \mathrm{~m}^{2}$, untuk kegiatan sosial 35 lokasi dengan luas 37,660 m², dan lahan yang dapat diproduktifkan 61 lokasi dengan luas 106,587 $\mathrm{m}^{2}$ yang hasilnya juga diperuntukan untuk pembiayaan keuangan masjid, hal ini dijelaskan oleh Kepala Kantor Urusan Agama Kecamatan yang penulis wawancarai.

Kondisi sosial masyarakat Kabupaten Tanah Datar yang agamis dan mempunyai falasafah ABS-SBK merupakan potensi bagi masyarakatnya untuk megembangkan dan meningkatkan pengelolaan wakaf. Masyarakat tentu akan mendukung program tentang produktifitas dan pemberdayaan wakaf.

Hal-hal yang terungkap menjadi kelemahan dalam pengelolaan wakaf antara lain 1) paham masyarakat yang jujur dengan apa adanya dan saling 
percaya antara satu dengan yang lainnya di masa awal pelaksanaan wakaf, pada kondisi sekarang memunculkan persoalan mengenai validitas legal tentang harta wakaf yang mengakibatkan harta wakaf tidak mempunyai bukti-bukti yang mampu menunjukan bahwa benda (tanah-tanah) tertentu merupakan tanah wakaf; 2) kesadaran masyarakat terhadap wakaf saat ini rendah. Hasil pendataan yang dilakukan oleh Kator Kementrian agama Kabupaten Tanah Datar tentang wakaf di daerah dan wawancara dengan KUA Kecamatan menunjukkan kesadaran masyarakat untuk berwakaf akhir-akhir ini sangat rendah dibandingkan dengan masa lampau katakanlah sebelum tahun 1990an. . Semenjak Undang-Undang Wakaf disyahkan hanya 16 lokasi (2,5\%) jumlah wakaf yang dilaksanakan dari 639 lokasi (100\%) jumlah wakaf keseluruhan di Kabupaen Tanah Datar.

Sumberdaya manusia pengelola wakaf sangat rendah. Pengelolaan harta wakaf produktif, sangat ditentukan keberhasilannya oleh sumberdaya Nazir wakaf. Nazir wakaf adalah seseorang atau sekelompok orang dan badan hukum yang diserahi tugas untuk mengelola wakaf dan memproduktifkannya. Data yang diperoleh dari lokasi penelitian menjelaskan bahwa Nazir wakaf itu keberadaannya hanya sekedar memenuhi persyaratan untuk membuat AIW atau untuk mengadminstrasikan benda wakaf. Hal ini juga dipicu karena peruntukan tanah wakaf kebanyakan untuk tempat ibadah dan sekolah. Pemeliharaan dan pengembangan tanah wakaf sangat ditentukan keberhasilannya dari perhatian dan dukungan oleh pemerintah daerah. Contoh dalam membuat AIW dan sertifikasi tanah wakaf yang diperuntukan untuk konsumtif tentunya memerlukan dana, sebaiknya pemerintah daerah mencarikan solusi untuk mendapatkan dana agar tanah wakaf punya bukti dan terdata secara baik. Kendala yang paling besar dalam pembuatan AIW dan sertifikasi tanah wakaf adalah masalah dana. Arif Zunzul Maizal pernah menawarkan kerjasama dengan PEMDA Tanah Datar tetapi tidak ada kejelasannya, artinya tidak dapat tanggapan dari PEMDA setempat. Perhatian PEMDA tentang wakaf mendapat perlakuan yang berbeda dengan zakat, pada hal bila wakaf terkelola dan dapat diproduktifkan akan lebih mensejahtarakan umat ketimbang zakat. Jumlah zakat terbatas sedangkan wakaf tidak dibatasi jumlahnya

Peraturan perwakafan ini baru berada dalam tatanan ideal dan belum terealisasi di dalam kehidupan masyarakat secara nyata. Sehinga masyarakat belum 
merasakan manfaat dari perwakafan ini untuk mengwujudkan kesejahteraan/ kemaslahan umat.

Perubahan sosial dan perkembangan ilmu pengetahuan serta tehnologi mempengaruhi sisstem sosial masyarakat dalam bidang perekonomian yang membawa masyarakat lebih konsumtif dan memberi pengaruh terhadap minat masarakat untuk melakukan perwakafan, karena harga jual tanah selalu meningkat dan kebutuhan masyarakat juga selalu meningkat sehingga masyarakat lebih termotivasi untuk memenuhi kebutuhannya sesaat. membawa dampak kehidupan masyarakat lebih konsumtif.

Ada beberapa hal merupakan peluang yang bisa dimanfaatkan untuk pemberdayaan wakaf di wilayah penelitian antara lain potensi wakaf yang belum terkelola secara optimal. Sampai saat ini di Kabupaten Tanah Datar, masih sedikit tanah wakaf yang berbentuk produktif dan dikelola secara produktif, sehingga manfaat wakaf belum dirasakan oleh masyarakat banyak. Pendataan Kemeterian Agama Kabupaten Tanah Datar tahun 2011 hanya 25 Nazhir wakaf yang mengelola wakaf produktif dan pada umumnya berbentuk sawah (14) dan pertanian (8) serta sebahagian kecil (3) yang berbentuk kolam ikan. Tanah wakaf yang produktif ini sangat membantu kegiatan peribadatan dan syiar Islam. Contohnya wakaf sawah berjumlah 11 lokasi yang dikelola oleh pengurus mesjid Makmur Jorong Tiga Batur di Kecamatan Sungai Tarab, minimal hasilnya satu kali panen berjumlah Rp 10.000.000 (sepuluh juta rupiah). Sayang wakaf ini belum dikelola oleh Nazhir yang berpengalaman dan mampu memberdayakan harta wakaf secara professional.

Mengotimalisasikan Pembinaan dan pengawasan terhadap Nazhir. Nazhir Wakaf adalah pihak yang perannya sangat mentukan dalam pengelolaan harta wakaf secara produktif. Tercapai tidaknya fungsi wakaf dalam mewujudkan potensi dan manfaat ekonomi harta benda wakaf untuk kepentingan ibadah dan untuk memajukan kesjahteraan umum, terletak pada peran Nazhir wakaf dalam mengelola harta wakaf.

Dukungan pemerintah daerah dan optimalisasi penetapan PERDA dan PERNAG. Kabupaten Tanah Datar yang mempunyai falsafa adat basandi syara', syara' basandi Khitabullah (ABS-SBK), dan seharusnya PEMDA sudah mempunyai peluang dan dukungan politik untuk membuat PERDA tentang wakaf. UndangUndang Nomor 22 Tahun 1999 tentang Otonomi Daeah juga memberi peluang 
untuk PEMDA bersama DPRD membuat PERDA tentang perwakafan. Seharusnya PEMDA berfungsi sebagai regulator, fasilitator, motivator, dan public sevice terhadap perwakafan di daerah khususnya dan di Indonesia umumnya.

Membahas masalah hukum Islam yang termasuk wilayah ijtihad, hal ini menjadikan masalah itu fleksibel, terbuka terhadap penafsiran-penafsiran baru, dinamis, futuristik (berorientasi pada masa depan). Sehingga dengan demikian, ditinjau dari aspek ajaran saja wakaf merupakan sebuah potensi yang cukup besar untuk dikembangkan sesuai dengan kebutuhan zaman. Fleksibelitas hukum wakaf ini telah terbukti dari sejarah peraturan perundangan-undangan yang ditetapkan di Indonesia.

Reinterpretasi paham wakaf di Kabupaten Tanah Datar perlu dilakukan dalam pemahaman tentang konsep wakaf, jenis harta benda yang diwakafkan, peruntukan dan system pengelolaan wakaf. Konsep fikih memberikan peluang untuk melakukan reinterpretasi tentang masalah yang memberi pengaruh terhadap perobahan sosial.

Lembaga penanggungjawab dalam pengelolaan wakaf di Indonesia secara nasional Undang-Undang wakaf mengamanatkan dengan pembentukan
Badan Wakaf Indonesia (BWI). Tugas dari lembaga ini adalah mengkoordinir Nazhirnazhir serta membina yang sudah ada dan menganti yang sudah lama dan yang tidak mempunyai kinerja yang baik. BWI dapat juga mengelola secara mandiri harta wakaf yang dipercayakan kepadanya, khususnya wakaf tunai.

Masalah wakaf yang mendasar di Kabupaten Tanah Datar adalah tidak berfungsinya Nazhir secara baik sebagaimanan yang diamanatkan UndangUndang Wakaf. Manakala perwakilan BWI dibentuk di Kabupaten Tanah Datar, tentu permasalahan tentang Nazhir dapat diminimalisir dan wakaf yang produktif dan yang berpotensi diproduktifkan dapat diberdayakan dan dikembangkan pemanfaatnya. Sehingga manfaat wakaf dapat dirasakan oleh masyarakat serta dapat membantu pembangunan masyarakat di daerah ini dalam mengentasan masalah kemiskinan.

Permasalahan yang menjadi hambatan dalam pemberdayaan wakaf di wilayah peneltian ini antara lain pengetahuan masyarakat tentang wakaf yang mimim. Paham umat Islam tentang wakaf di Kabupaten Tanah Datar sangat sederhana sekali diwarisi dari orang tuanya secara turun temurun yang diterima secara lisan. Jarang dilakukan evaluasi serta kajian yang 
mendalam. Walaupun sudah ada UndangUndang dan Peraturan pemerintah tentang wakaf, tetapi peraturan ini belum disosialisasikan kepada masyarakat banyak. Sehingga masyarakat tidak tahu apa yang diatur dalam peraturan wakaf ini.

Salah satu masalah yang menjadi hambatan dalam produktifitas dan pemberdayaan benda wakaf di Kabupaten Tanah Datar adalah keberadaan Nazhir yang mengelola benda wakaf, yang adanya sama dengan tidak ada. Pada umumnya Nazhir di daerah ini hanya muncul namanya sewaktu membuatkan AWI dan sertifikat wakaf, setelah itu nazhir tidak kenal lagi dengan benda wakaf yang ia sebagai Nazhirnya. Nazhir wakaf seperti ini dapat dikatakan Nazhir tradisional. Belum berfungsi sebagaimana mestinya mengelola dan mengembangkan produktifitas dan pemberdayaan benda wakaf.

Peruntukan tanah wakaf di Kabupaten Tanah Datar pada umunya adalah untuk sarana peribadan, dari 639 lokasi tanah wakaf 270 lokasi untuk masjid, 177 lokasi untuk mushallah, 95 lokasi untuk madrasah, 61 lokasi untuk produktif, 35 lokasi untuk sosial dan satu lokasi untuk kuburan. Kondisi peruntukan wakaf seperti ini menjadi hambatan untuk memproduktifkan dan memberdayakan benda wakaf. Karena kewenangan penentuan peruntukan wakaf terletak pada Wakif, dan Nazhir tidak punya kewenangan untuk merubah peruntukan benda wakaf.

Problematik yang menjadi hambatan dalam pembuatan AIW dan sertifikat wakaf di Kabupaten Tanah Datar, dapat dipahami dari hasil pengumpulan data dari KUA kecamatan yang penulis lakukan antara lain 1) umumnya tanah di daerah ini banyak yang tidak punya sertifikat, karena termasuk hak ulayat kaum, yang tidak dimiliki secara pribadi dan banyak juga tanah yang tidak punya surat menyurat; 2) pelaksanaan wakaf yang dilakukan secara lisan atas dasar kepercayaan saja, sehingga tanah wakaf tidak punya data adminstrasi atau tidak mempunyai bukti perwakafan seperti surat-surat yang memberi keterangan bahwa tanah tersebut telah diwakafkan; 3) minat masyarakat yang rendah untuk membuatkan AIW dan sertifikat wakaf. Mereka beralasan wakaf adalah ibadah dan tidak mungkin ada yang menyalah gunakan. Kenyataan di Kabupaten Tanah Datar memang belum ada tanah wakaf yang diperkarakan; 4) tidak tersedianya dana atau sulit mengusahakan dana untuk membuat AIW dan sertifikat tanah wakaf.

Hambatan yang klasik dari peningkatan produktifitas dan pemberdayaan benda wakaf di Kabupaten Tanah Datar 
adalah tidak tersedia dana untuk itu. Di daerah ini belum ada alokasi dana yang khusus di anggarkan untuk pengelolaan dan pengembangaan harta wakaf. Sehingga peningkatan pemberdayaan dan produktifitas benda wakaf menjadi terhalang. Pada umumnya KUA kecamatan membuatkan program tahunan tentang wakaf seperti tentang pensertifikatan tanah wakaf, tetapi tidak bisa terlaksana karena tidak ada dana yang tersedia. Begitu juga tentang program pembinaan dan pemberdayaan Nazhir tidak dilaksanakan karena tidak ada dananya.

\section{KESIMPULAN}

Setelah dilakukan pengumpulan data di lapangan dan kemudian diolah sesuai dengan metode yang telah ditetapkan, dapat disimpulkan hasil penelitian bahwa potensi pemberdayaan tanah wakaf di Kabupaten Tanah Datar dapat ditingkatkan dengan melakukan hal-hal seperti 1) penguatan regulasai peraturan perundangan wakaf di daerah; 2) pembentukan mitra usaha; 3) penguatan kualitas SDM berwawasan syariah; 3) dukungan keuangan yang cukup; dan 4) pemanfaatan peluang wakaf dalam pemberdayan dan produktifitas benda wakaf oleh nazhir.

Kondisi Nazhir wakaf di Kabupaten Tanah Datar sangat memprihatikan.
Pengangkatan Nazhir hanya sekedar untuk memenuhi syarat untuk membuat AIW dan mensertifkatkn tanah wakaf. Supaya tanah wakaf di daerah penelitian dapat ditingkatkan produktifitas dan pemberdayaanya, maka Nazhir membutuhkan pembinaan dan pengawasan serta bantuan dukungan dana.

\section{KEPUSTAKAAN ACUAN}

Abdul Halim, Hukum Perwakafan di Indonesia, (Ciputat: Ciputat Press. 2005)

Achmad Junaidi, Thobeib Al-Asyhar, Menuju Era Wakaf Produktif, (Jakarta: Mumtaz Publishing. 2007)

Ahmad Rofiq, Hukum Islam di Indonesia, (Jakarta: Raja Grafindo Persada, 1998)

Amiruddin, Zainal Asikin, Pengantar Metode Penelitian Hukum, (Jakarta: Rajawali Pers, 2004)

Burhan Ashshofa, Metodologi Penelitian Hukum, (Jakarta : PT. Rineka Cipta, 2004)

Cik Hasan Bisri, Kompilasi Hukum Islam dalam Sistem Hukum Nasional, (Jakarta : Logos. 1999)

Daud Ali, Muhammad. Sistim Ekonomi Islam Zakat dan Wakaf, UI Press, Jakarta,1988

Dahlan, Abdul Azis, Ensiklopedi Hukum Islam, Ichtiar Baru Hoeve, Jakarta, 1997 
Depag. RI (2007), Fiqih Wakaf, Direktorat

Pemberdayaan Wakaf Direktorat

Jenderal Bimbingan Masyarakat Islam (2007), Paradigma Baru Wakaf di

Indonesia, Direktorat Pemberdayaan

Wakaf Direktorat Jenderal Bimbingan

Masyarakat Islam

(2007), Panduan Pemberdayaan TanahWakaf

Produktif Strategis di Indonesia, Direktorat

Pemberdayaan Wakaf Direktorat Jenderal

Bimbingan Masyarakat Islam _(2007), Strategi Pengembangan

Wakaf Tunai di Indonesia, Direktorat

Pemberdayaan Wakaf Direktorat

Jenderal Bimbingan Masyarakat Islam Al-Qur'an al-Karim dan Terjemahannya,

(Semarang: CV. Toha Putra, 1996) , Undang-undang Nomor 41 Tahun

2004 dan Peraturan Pemerintah Nomor 42 Tahun 2006, (Jakarta : Direktorat Pemberdayaan Wakaf, 2007).

Depdikbud, Kamus Besar Bahasa Indonesia, (Jakarta: Balai Pustaka, 1994)

Elimartati, Hukum Perdata Islam di Indonesia, STAIN Batusangkar Press, Batusangkar ,2010
Efrison, Pesona dan Profil Luhak Nan Tuo, Kantor Inforkom dan PDE Tanah Datar,Batusangakar

Juhaya S. Praja, Perwakafan di Indonesia (Peraturan Pemerintah Nomor 28 tahun 1977), (Bandung: Yayasan Piara. 1995)

Kahlani, Muhammad bin Ismail, Subul alSalam, Dahlan, Bandung,tt

KANDEPAG Kabupaten Tanah Datar Laporan Perkembangan Harta Wakaf Kabupaten Tanah Datar, ( Batusabgkar ,2009

Khatib, Syarbaini, Mungni al-Muhtaj, Dar al- Fikr, Beirut, 1978

Satria Effendi M. Zein, MA. Problematika Hukum Keluarga Islam Kontemporer, (Jakarta Timur: Prenada Media, 2004)

Sayyid Sabiq, Fiqh Sunnah Juz 3, (Kairo : Dar al-Fath, 1983)

Syaukani, al-Nail al-Authar, Dar al- Fikr, tt Usman. Suparman, Hukum Perwakafan di Indonesia, Darul Ulum Press,Kudus, 1994 